Omni-Akuatika Special Issue 3 $3^{\text {rd }}$ Kripik SCiFiMaS 2020: 33 - 41
ISSN: 1858-3873 print / 2476-9347 online
Research Article
journal homepage: http://ojs.omniakuatika.net

\title{
The Fishing Ground of Bottom Longline Vessels and Exploitation Rate of Tiger Grouper (Epinephelus Aerolatus) in Arafura Waters
}

\author{
Andina Ramadhani Putri Pane ${ }^{1 *}$, Reza Alnanda ${ }^{2}$, Prihatiningsih ${ }^{1}$, Hufiadi $^{1}$ and Ali Suman ${ }^{1}$ \\ ${ }^{1}$ Research Institute for Marine Fisheries, Jl. Raya Bogor KM 47 Cibinong, Bogor, Indonesia \\ ${ }^{2}$ Pontianak State Polytechnic, Jend Ahmad Yani Street, Pontianak. \\ *Corresponding author: paneandina@gmail.com
}

Received 20 November 2019; Accepted 1 October 2020; Available online 31 December 2020

\begin{abstract}
As excessive capture activity adversely impacts fisheries sector, fish resources management is a necessity. This study was conducted as a scientific contribution for the managements of bottom longline fisheries in Arafura Waters and areolate grouper (Epinephelus areolatus) as one of the target catches. It was carried out from February to December 2017 and in November 2018. Data on the fishing grounds of eight bottom longline vessels were obtained from the vessel monitoring system (VMS) of Probolinggo Marine and Fisheries Resources Supervisory Unit, Mayangan Probolinggo Fishing Port, and Marine and Fisheries Resources Surveillance (PSDKP) Tual Station. Based on the analysis of the coordinates from the VMS, the fishing grounds of the bottom longline vessels in Arafura waters were found around Dolak until the border with Merauke and around Timika until Aru Islands. The composition of dominant catches consisted of croaker (Pennahia spp.) and snapper (Lutjanus spp.), as well as grouper (Epinephelus spp.) in a smaller proportion. The size structure of the areolate grouper caught with bottom longlines was $21.5-54.5 \mathrm{cmTL}$; its length at first capture (LC) was $33.9 \mathrm{cmTL}$; and its asymptotic length was 70.5 $\mathrm{cmTL}$. Its growth rate $(\mathrm{K})$ was found 0.26 per year. The fishing mortality $(F)$ of the species was found higher than its natural mortality (M), and its exploitation level $(E)$ was 0.74 , meaning that the species was already overfished. The exploitation should be reduced by $40-50 \%$ to keep the fish resources in Arafura sustainable, especially for areolate grouper.
\end{abstract}

Keywords: fishing ground, bottom longline, exploitation level, tiger grouper, Arafura

\section{ABSTRAK}

Penangkapan yang dilakukan secara signifikan akan memberikan dampak bagi perikanan sehingga diperlukan upaya pengelolaan sumberdaya ikan. Penelitian ini dilakukan dalam rangka memberikan kontribusi secara ilmiah dalam pengelolaan perikanan rawai dasar di Arafura dan sumberdaya ikan kerapu macan (Epinephelus aerolatus) sebagai salah satu target hasil tangkapan. Penelitian dilakukan dari Februari sampai dengan Desember 2017 dan Nopember 2018. Data lokasi penangkapan ikan delapan kapal rawai diperoleh dari vessel monitoring system (VMS) Satuan Pengawasan Sumberdaya Kelautan dan Perikanan Probolinggo, Pelabuhan Perikanan Mayangan Probolinggo dan Pangkalan Pengawasan Sumberdaya Kelautan dan Perikanan (PSDKP) Tual. Berdasarkan analisa titik koordinat dari VMS maka diketahui bahwa kapal rawai sepanjang tahun berada di perairan Arafura sekitar Dolak sampai dengan perbatasan Merauke dan sekitar Timika sampai dengan Kepulauan Aru. Kompisisi hasil tangkapan dominan ikan gulama (Pennahia spp), ikan kakap (Lutjanus spp) dan sebagaian kecil ikan kerapu (Epinephelus spp). Ikan kerapu macan (E.aerolatus) yang tertangkap dengan rawai mempunyai struktur ukuran 21,5 - 54,5 cmTL dengan ukuran pertama kali tertangkap (Lc) adalah 33,9 cmTL. Laju pertumbuhan (K) ikan kerapu 0,26 per tahun dengan panjang asimtotiknya 70,5 cmTL. Laju kematian akibat penangkapan ( $F$ ) lebih tinggi dibandingkan dengan laju kematian alamiah (M) dan tingkat pemanfaatan ikan sebesar $E=0,74$, artinya sudah over fishing. Pengurangan pemanfaatan sebesar 40 - $50 \%$ harus dilakukan agar kelestarian ikan di Arfura dapat dipertahankan khususnya ikan kerapu macan.

Kata Kunci: daerah penangkapan ikan, rawai dasar, tingkat pemanfaatan, kerapu macan, Arafura 


\section{Introduction}

Arafura waters have long become productive with fishery resources such as shrimp, demersal fish, reef, and pelagic fish. The existence of these abundant natural resources is due to the waters having a fertile upwelling pattern and the occurrence of a mixture of freshwater mass from the mainland of Papua with the mass of seawater (Hasanudin, 1998; Suman et al., 2016), namely when the water in the layer is driven until to the Java sea and Natuna sea by the east wind. The wealth of these fishery resources makes Arafura become a fishing ground for fishing vessels. The potential of these marine fisheries resources contributes to $20 \%$ of the potential of national fisheries (Suman et al., 2016). Even the production of exported fisheries contributes to $13 \%$ of the potential of national fisheries and $30 \%$ of Indonesia's total fishery exports (Pranowo et al., 2013; Afandy, 2016).

The Arafura waters are bordered by the Banda Sea to the north, to the east by the Torres Strait, to the south by Australia's northern waters, and to the west by the Banda Sea and Timor Sea (Ramadyan \& Radjawane, 2013). Areas that belong to the Arafura waters from Merauke to Timika and the Aru Islands region. Fishing in these waters has long been carried out by a fleet of vessels with trawling, trawl fishing nets, fishing nets, and many are operated by foreign vessels. Even it was reported that ships from Thailand and Taiwan have been operating since 1700 (Prisantoso \& Badrudin, 2010). Based on KEPPRES No. 39 of 1980 the use of trawls is only allowed in Arafura waters.

As fishing efforts increase, the areas of this water are vulnerable to illegal fishing, overfishing, and destruction of fish habitat and the environment, which threatens the sustainability of resources (Mulyana et al., 2011; Mulyana et al., 2012; Purwanto, 2015). Through the Regulation of Marine and Fisheries Minister (PERMEN KP) Number 56 of 2014 concerning the Temporary Termination (Moratorium) of Fisheries Business Licensing in WPPNRI, foreign vessels are no longer fishing in these waters. Meanwhile, through the Regulation of Marine and Fisheries Minister (PERMEN KP) Number 2 of 2015 concerning the prohibition of the use of trawls and seine nets in WPP RI, the trawls which dominantly operate in Arafura are no longer used for catching fish.

Before the moratorium, fishing vessels with squid fishing line, bottom longline, and gillnet fishing gear were those that had a higher level of sustainability compared to trawlers and shrimp trawlers (Mulyana et al., 2012). After a moratorium, however, the foreign vessels and trawls are replaced with fishing vessels with bottom longline, gillnets and purse seine. Besides coming from Papua, the ship also came from the surrounding waters, namely from Probolinggo, Juwana, Indramayu, Jakarta, Bali, and Makassar. To minimize violations committed by fishing vessels, the government through the Ministry of Marine and Fisheries stipulates that vessels above 30 gross tonnages (GT) must be equipped with a vessel monitoring system (VMS). VMS is a ship monitoring system that determines the position of the ship, fishing ground, vessel activity, type, and many catches, and other information (Gunawan et al., 2019). So, monitoring online will be carried out and action can be taken if there are vessels indicated conducting illegal fishing activities.

Demersal fish and coral are dominantly captured by the bottom longlines and dominant nets. Demersal fish is the biggest number of catching in Arafura, which reaches $58.89 \%$ of the total catch. Besides, there are other types such as pelagic fish around $11.36 \%$, crabs $9.88 \%$, and shrimp about $7.8 \%$ and others less than 4\% (Pranowo et al., 2013). More than 230 species of demersal fish in the waters of the Arafura and even demersal fish dominated the catches although fishing gear used was shrimp trawl (Sumiono \& Hargiyatno, 2012; Widodo in Purwanto, 2015). The type of reef fish that has high economic value and is in demand by consumers is grouper because of its savory taste. Even according to Rochmady \& Susiana (2014) this fish has a high level of nutrition. Groupers are favored seafood in the market of middle and upper classes in the state of Kuwait, Indonesia, Malaysia, Singapura, Japan, China, and Mexico (Shakeel and Ahmed in Nickerson \& Maniku, 1997). Although this fish is not the dominant catch of both bottom longline vessels and gillnets, it still has a high selling price. This fish can be captured by bottom longlines and gillnets because the gillnets reach the bottom of the water. The increasing demand and grouper fishing effort will spur the increased levels of their exploitation rate. Demersal fish and coral are also fish with slow-growing nature or are called slow-growing species so that they become vulnerable to high fishing pressures.

Grouper in Indonesia consisted of 39 species Mujiyanto \& Sugianti (2014), but the dominant capture in Arafura waters and Probolinggo land was tiger grouper (Epinephelus aerolatus). In carrying out 
management, scientific studies are needed that can be used as a basis for maintaining fish populations. This study discusses the areas of fishing with bottom longline fishing gear based on the VMS and the level of exploitation rate of tiger grouper fish in Arafura waters. The results of the study were intended to become the basis for fish management in Arafura waters, especially regarding fishing ground for bottom longline fishing gear and maintaining the population of tiger grouper (E. aerolatus).

\section{Material and methods}

\subsection{Data collection}

The study was conducted in Arafura waters by sampling from two sampling sites in Probolinggo and Tual from February to December 2017 and in November 2018 using a survey method. The data collection of catches was done by observing and recording the number of catches of several fishermen using bottom longline every month. Data collection activities were assisted by enumerators at fish landing sites from bottom longline vessels that capture in Arafura waters monthly. The number of bottoms longline the vessel monitoring system (VMS) data was obtained from the Supervisory Unit Maritime and Fisheries Resource Monitoring Probolinggo and Fishing Port Mayangan Probolinggo is 96 units and 3 units are samples. While number the Base Directorate General of Marine and Fisheries Resources Surveillance (PSDKP) Tual is 200 units and 5 vessels for samples fishing ground. Observations and measurements of samples of tiger grouper were as many 2,681 individuals fish samples. The measurement of the total length of fish was from the mouth to the tip of the fish. Tiger grouper (Epinephelus aerolatus) is presented in Figure 1.

\subsection{Data analysis}

Data from the VMS have been obtained from three vessels at the Fishing Port Mayangan Probolinggo, namely Lautan Berlian, Sabang Maju, and Prima Jaya ships from

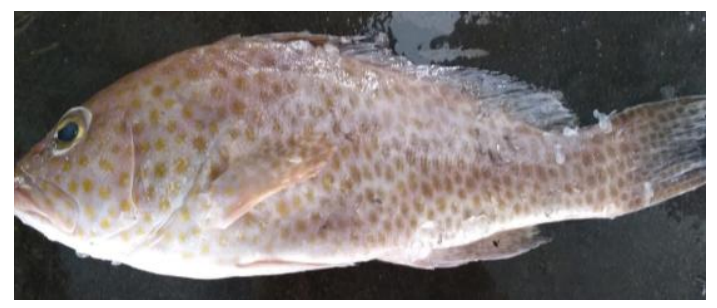

Figure 1. Tiger grouper (Epinephelus aerolatus)
September 2017 to September 2018. The VMS data from the Directorate General of Marine and Fisheries Resources Surveillance (PSDKP) at Tual included five ships, namely Fico Sejahtera, Pesona Mandiri, Bright Moonlight III, Bintang Laut II, and Pesona Pasifik from January to November 2018. The coordinate data were analyzed based on the position of latitude and longitude each month and presented on the map.

Fishermen's catch was tabulated and analyzed to obtain the number of dominant catches and the composition of the catching with bottom longline fishing gear. The first length at capture (Lc) was obtained by plotting cumulative frequencies with each total fish length, so a standard logistic curve was obtained, where the intersection between $50 \%$ of curve cumulative frequency is the length when $50 \%$ of fish are captured. The value of $\mathrm{K}$ growth parameters and asymptotic length were analyzed by the ELEFAN I method Gayanilo et al (1994) and the growth parameter to was calculated through the Pauly in Sparre \& Venema (1992). Furthermore, the rate of fishing mortality $(F)$ can be obtained by using the Total mortality $(Z)$ with the natural mortality rate $(M)$ or $F=Z-M$ and the exploitation rate $(E)$ is calculated as $E=F / Z$ (Sparre \& Venema, 1999).

\section{Result and discussion}

\subsection{Fishing Ground}

Coordinate points of eight bottom longline vessels were from Probolinggo both from the vessel monitoring system (VMS) of the Mayangan Fishing Port and the VMS of Directorate General of Marine and Fisheries Resources Surveillance (PSDKP) Tual from September to December 2017 and January to September 2018. It was found that bottom longline vessels throughout the year in the

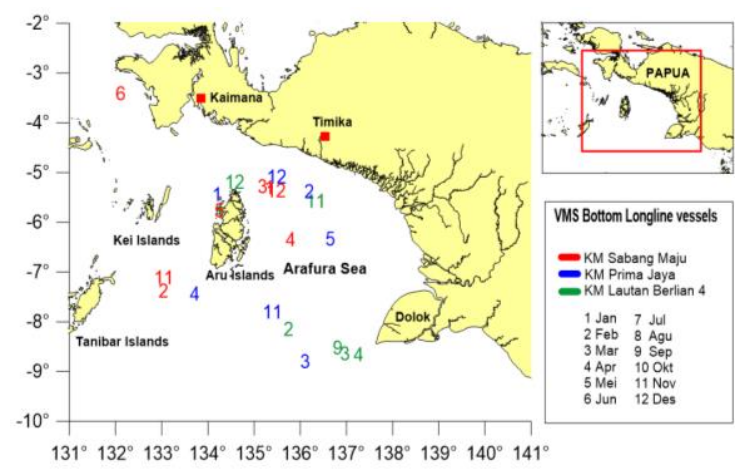

Figure 2. Fishing ground of bottom longline in Arafura Waters based VMS FP Probolinggo 
waters of Arafura. The position of the ship showed fishing activities around the Aru Islands up to Dolok waters bordering Merauke and in Timika to Kaimana waters adjacent. Some vessels made landfall on catches and filled up fishing supplies in Aru Archipelago waters, namely on Wamar Island (Dobo) (Figure 2 and Figure 3). Fishing ground of bottom longline vessels (Figure 4) remained the same even before moratorium in the waters of Aru, Dolak and Merauke (Suryanto \& Widodo, 2011). This finding suggests that there is no significant change in the area of fishing with bottom longline fishing gear, and shows that the waters of Arafura still produce a lot of fish resources. The abundance of fish resources is closely related to fertile waters and provides sufficient food for individuals to survive.

The Aru Islands are a $62.36 \%$ potential fishing zone (ZPPI) which is possible due to the abundance of food for fish resources (Tambun et al., 2018). An adequate food chain is directly proportional to the amount of plankton both phytoplankton and zooplankton available as a food source for fish. Phytoplankton is also the biggest contributor of oxygen in the waters because it has the role of binding to solar energy and as an indicator of water fertility (Ismunarti, 2014). Zooplankton as phytoplankton consumers become a liaison with small fish and big fish because they become a source of fish stimulants to approach. The waters around the Aru Islands have the highest plankton abundance with a density of 19,185,287 cells / $m 3$ (Wijopriono et al., 2007). The fertility of Arafura waters is also influenced by the upwelling and down welling processes (Pranowo, 2012). Fishing ground of bottom longline vessels depends on water fertility, changes in climatology and oceanographic waters (Sadhotomo \& Suprapto, 2013).

Bottom longline fisheries were initially based on the island of Sumatra, Tanjungbalai

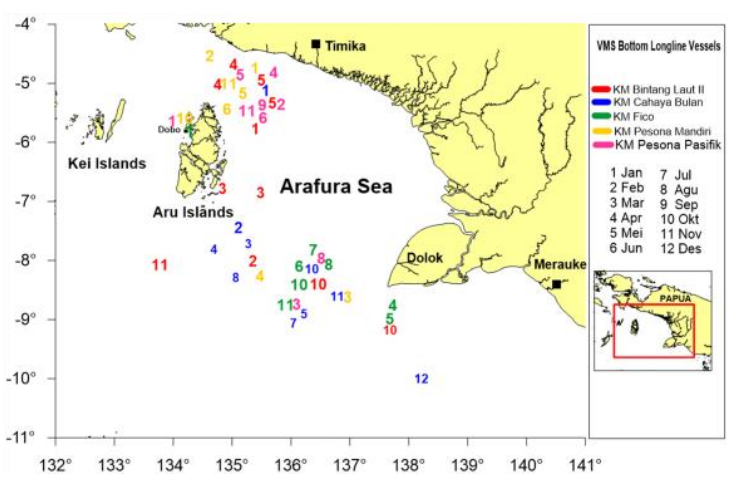

Figure 3. Fishing ground of bottom longline in Arafura Waters based VMS PSDKP Tual
Karimun, Riau and flourished in these waters from the 1990s with landing bases in Probolinggo and partly in Kupang (Badrudin et al., 2004). Vessels of bottom longline based in Probolinggo are made of wood with the weight of the boat varies, ranging between 43 - $98 \mathrm{GT}$, average of $70 \mathrm{GT}$. The driving machine used a magnitude ranging between 220-360 PK with 10-12 crew.

Construction of bottom longline of this consists of a main rope, branch rope, hook, float and sinker. The overall length of the main rope reaches $8000 \mathrm{~m}$, where at a distance of $3 \mathrm{~m}$ hung a branch rope $(1.5 \mathrm{~m}$ long $)$ and at the end was given a fishing line (No 6 or 8 ). The number of hooks in the chain reaches $6,000-11,000$ hooks. This fishing gear is considered capable of protecting the population because the size of the hook can be adjusted to the length of the fish that can be capture. According to Bahtiar et al (2013) this tool is considered to be more selective in catching fish so that the population can be maintained and is considered be environmentally friendly and the instrument saves energy as well because of its passive operation.

\subsection{Catch unit effort (CPUE) and catch composition}

The catch unit effort (CPUE) of bottom longline vessels in Arafura waters averaged 30.3 tons / unit with the highest yield in January of 48.7 tons / unit. The lowest CPUE value in December was 16.5 tons / unit. The highest production from longline vessels in May was $1,487.7$ tons and the lowest in December was around 132.1 tons (Table 1). The low CPUE value in December can occur because the fish famine season runs from December to March (Suman et al., 2017). The composition of the catch that landed at Probolinggo Fishing Port was dominated by gulama fish (Pennahia spp) as much as $19.3 \%$ of the catch, Arius spp

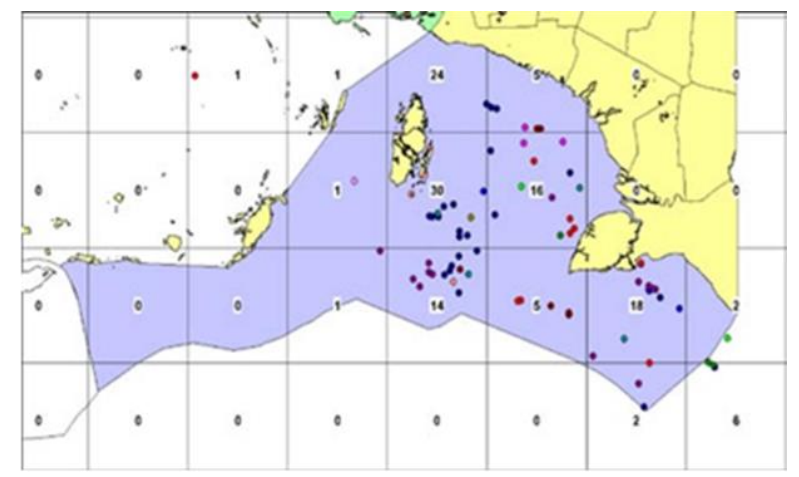

Figure 4. Fishing ground of bottom longline in Arafura waters (Source: Suryanto \& Widodo, 2011) 
Table 1. Catch unit effort of bottom longline in Arafura waters, 2017

\begin{tabular}{|c|c|c|c|}
\hline Months & Effort (Unit) & Production (Tons) & CPUE (Ton.Effort ${ }^{-1}$ ) \\
\hline January & 25 & 1216.5 & 48.7 \\
\hline February & 44 & 1154.6 & 26.2 \\
\hline March & 48 & 1363.9 & 28.4 \\
\hline April & 54 & 1435.3 & 26.6 \\
\hline May & 49 & 1487.7 & 30.4 \\
\hline June & 34 & 983.8 & 28.9 \\
\hline July & 30 & 627.2 & 20.9 \\
\hline August & 16 & 746.8 & 46.7 \\
\hline September & 8 & 149.6 & 18.7 \\
\hline October & 21 & 709.9 & 33.8 \\
\hline November & 25 & 949.0 & 38.0 \\
\hline December & 8 & 132.1 & 16.5 \\
\hline
\end{tabular}

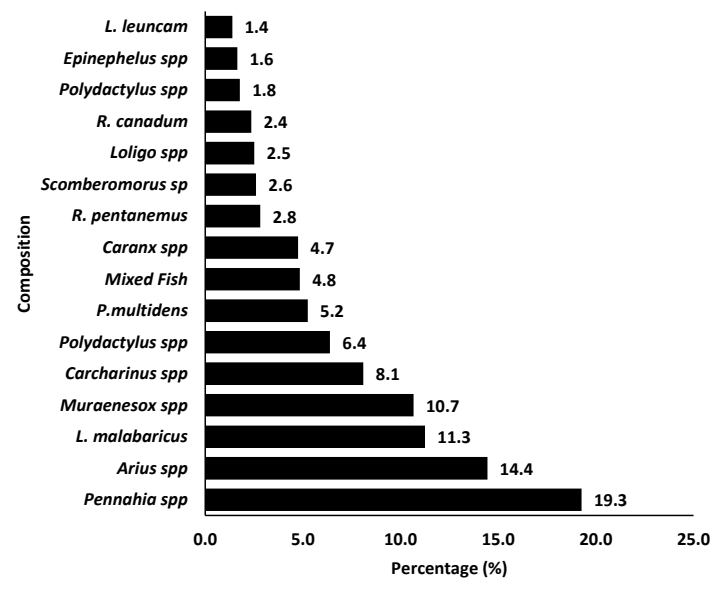

Figure 5. Catch composition landing in Probolinggo, 2017

$14,4 \%$, red snapper (Lutjanus malabaricus) $11.3 \%$ and grouper (Epinephelus spp) 1.6\% (Figure 5). The dominant bottom longline catches of gulama fish (Pennahia spp) and grouper fish (Epinephelus spp) were 1.8\% (Figure 6). This bottom longline makes demersal fish and reef fish economically valuable. Those types of fish become the main targets of fishing.

\subsection{Length frequency}

The frequency length of groupers captures by bottom longline and gillnets landed at Probolinggo during the study period was 21.5 $54.5 \mathrm{~cm}$. The total length (TL) of frequency is presented in Table 2. Dominant fish at length $39.5 \mathrm{cmTL}$ with distribution below $40 \mathrm{~cm}$ was $81 \%$ (Figure 7 ). E. aerolatus maximum length of $47 \mathrm{cmTL}$ and generally $35 \mathrm{cmTL}$ (Fish Base, 2019). However, based on the research of Shakeel \& Ahmed (1997) this fish was captured at length $42 \mathrm{~cm}$ in the medium grouper, while

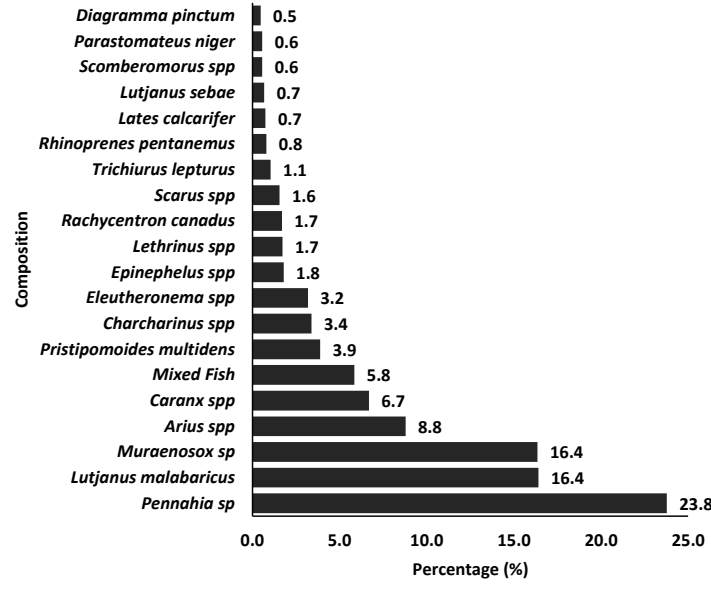

Figure 6. Catch composition of bottom longline landing in Probolinggo, 2017

the length of the large grouper was found to be $60 \mathrm{~cm}$. The length of these fish in Terengganu waters, Malaysia from length $13.7 \mathrm{~cm}$ up to 48.8 $\mathrm{cm}$ (Mat Piah et al., 2017). Differences in length can occur due to differences in the environment of fish habitat. Young groupers live at a depth of 0.5 - $3 \mathrm{~m}$ while adult fish live at a depth of 7-40 $\mathrm{m}$ (Tadjuddah et al., 2013). Grouper fish is a reef fish that naturally lives permanently but moves with a specific purpose (Ogden \& Quinn in Mujianto \& Sugianti, 2014).

3.4. The first length at capture $\left(L_{c}\right)$, growth parameters $(\mathrm{K})$ and Exploitation Rate $(\mathrm{E})$.

Based on the analysis of the length frequency, the first length at capture (LC) of the tiger grouper in Arafura waters was $33.9 \mathrm{cmTL}$ (Figure 8). Based on the research of Shakeel \& Ahmed's study in Nickerson \& Maniku (1997) this fish experienced gonad maturity at $25 \mathrm{~cm}$ medium grouper but the length of large grouper was $39 \mathrm{~cm}$. Compared to the results of research 
Table 2. Length frequency of tiger grouper (E. aerolatus) in Arafura waters

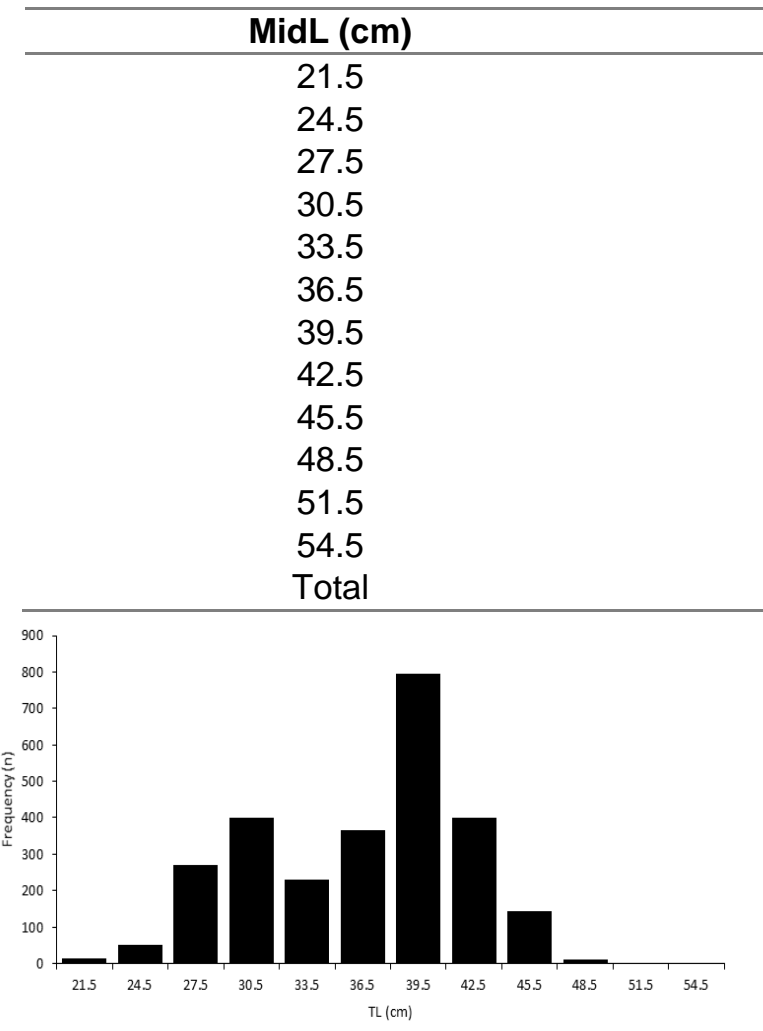

Figure 7. Length frequency of tiger grouper (E. aerolatus)

on Goat Island and Kuala Dungu, Terengganu, Malaysia that these fish are gonad maturity on the length $32.60 \mathrm{~cm}$ and $35.70 \mathrm{~cm}$ (Kadir et al., 2016). In fact, it is stated that this grouper fish in the Red Sea length below $20.2 \mathrm{~cm}$ is immature and length above $24.7 \mathrm{~cm}$ has matured with the first length at mature the female gonad ripe is $23.5 \mathrm{~cm}$ (Mahmoud, 2009). Furthermore, a recent study in Suez Bay showed that females under $18 \mathrm{~cm}$ were still immature (Osman et al., 2018), whereas mature gonads were found to be more than $32 \mathrm{~cm}$ with a minimum length of mature gonads of $25.5 \mathrm{~cm}$. So, from the comparative data it can be estimated that the length first at capture in Arafura includes fish that have experienced gonad maturity.

The growth coefficient $(K)$ value of tiger grouper and maximum length $(L \infty)$ is $0.24 /$ year and $70.5 \mathrm{cmTL}$. The growth coefficient (K) indicates the level of time it takes an individual to reach its asymptotic length Sparre \& Venema, 1999). The value of this growth coefficient is not much different from those which were found in Kuwait which is 0.288 / year, but the asymptotic length is $39.10 \mathrm{~cm}$ (Mathews \& Samuel in Marzuki \& Djamal,

\begin{tabular}{c} 
Frequency (n) \\
14 \\
51 \\
270 \\
399 \\
231 \\
366 \\
794 \\
400 \\
143 \\
11 \\
1 \\
1 \\
2681 \\
\hline
\end{tabular}

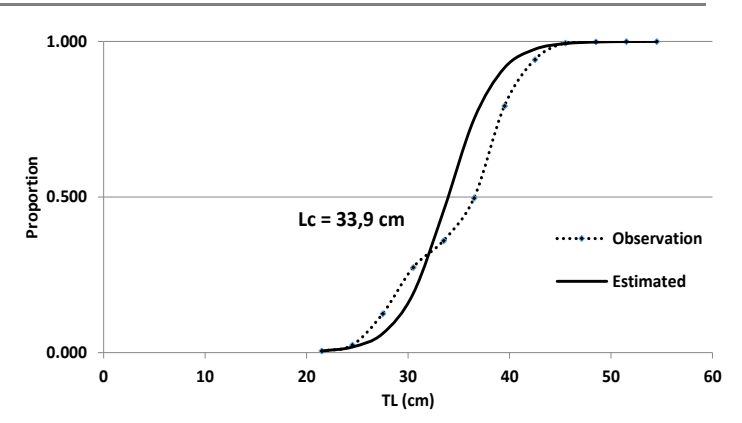

Figure 8. Length of the first capture $\left(L_{c}\right)$ of E.aerolatus in Arafura waters

1992), Suez Bay $K=0.154$ and $L \infty=66.65 \mathrm{~cm}$ (Abd-Allah et al., 2015) and in the Red Sea K = 0.13 and $L \infty=78.92 \mathrm{~cm}$ (Hasan in Abd-Allah et al., 2015). Different length infinity was found in the Red Sea compared to Arafura, Suez Bay and Kuwaiti. Differences in growth coefficient and length infinity can occur due to the aquatic environment and the amount of food available.

Based on the value of growth coefficient $(K)$ and fish length infinity $(L \infty)$, it can be determined the value of natural mortality rate (M) and fishing mortality (F) which is 0.59 / year and $1.65 /$ year (Table 3 ). The high value of fishing mortality was 3 times more than than natural mortality suggesting that this fish has more mortality exploitation rate. Fishermen who usually do fishing operations in the morning and evening can be the cause of high fishing mortality. This is because it is related to the migration patterns of reef fish which look for food at dawn and dusk (Mujianto \& Sugianti, 2014).

Based on analysis, the exploitation rate $(E)$ of tiger grouper in Arafura waters is 0.74, which means that the exploitation rate is considered to be over fishing. Reduce the exploitation effort by $40-50 \%$ of the current situation. In general, 
Table 3. Population parameters of tiger grouper (E. areolatus) in Arafura waters

\begin{tabular}{lcc}
\hline \multicolumn{1}{c}{ Parameter } & Unit & Value \\
\hline First length at capture $\left(\mathrm{L}_{\mathrm{c}}\right)$ & $\mathrm{cm}$ & 33.9 \\
Fish length infinity $(\mathrm{FL} \infty)$ & $\mathrm{cm}$ & 70.5 \\
Growth coefficient $(\mathrm{K})$ & per year & 0.26 \\
Life at length equals zero $(\mathrm{t}$ 0) & per year & -0.508 \\
Total mortality $(\mathrm{Z})$ & per year & 2.24 \\
Natural mortality $(\mathrm{M})$ & per year & 0.59 \\
Fishing mortality $(\mathrm{F})$ & per year & 1.65 \\
Exploitation rate $(\mathrm{E})$ & $\%$ & .74 \\
\hline
\end{tabular}

the status of over exploitation in Arafura waters for demersal and coral fisheries has long occurred due to fishing using fishing trawlers (Mahulette \& Samu-samu, 2014; Purwanto, 2015). Even based on the Decree of the Minister of Marine and Fisheries Number 50 Year 2017 concerning Estimation of Potential, Number of Catches Permitted, and Level of Exploitation Rate of Reef Fish Resources in the Fisheries Management Region of the Republic of Indonesia in WPP 718 is $E=1.07$ with a limit of $E>1$ is categorised as a case of over exploitation. This category means that based on the KP Ministerial Decree, activities on catching the reef fish must be reduced.

The moratorium on foreign ships and banning of trawls uses are expected to have impact on recovering fish and shrimp resources (Afandy, 2016). The moratorium policy that was set to prohibit the operation of foreign vessels causing the resurgence of people's fisheries in Arafura waters. This policy is considered to have a positive influence on small fishermen and provides opportunities for capture fisheries industry in a wider score (Suman \& Satria, 2014). However, the policy to reduce the capture effort must be carried out across sectors considering that the implementation of the policy must be supported by all relevant stakeholders (Suhana, 2015). The government can also arrange some regulation on the minimum length of grouper which can be traded in order to protect the small grouper population.

\section{Conclusions}

The fishing ground of the bottom longline in Arafura waters throughout the year in Arafura waters. Fishing is carried out from around the Aru Islands up to Dolok waters bordering Merauke and in the waters around Timika. One of the fish captures with bottom longline and gillnets in these waters is the tiger grouper (Epinephelus aerolatus) with the exploitation rate reaching $E=0.74$. This number suggests that a need for a reduction in catching activity by $40-50 \%$ of what has been done so far. This action is to keep the tiger grouper fish population.

\section{Acknowledgment}

This paper is a contribution from the Study on Fisheries Biological Characteristics Resources Habitats, and Potential Productions of Fish Resources in FMA 718 Arafura sea, Fiscal year 2017 and 2018 by the Research Institute for Marine Fisheries, Bogor, Indonesia. Researchers are thankful to Suprapto and Prof. Ali Suman as the PIC of the study activities in FMA 718 for Year 2017 and 2018, Office Head of Supervisory Unit Maritime and Fisheries Resource Monitoring Probolinggo, Fishing Port Mayangan and Supervision Base Maritime and Fisheries Resource Monitoring Tual for their assistance and cooperation in providing data from Vessel Monitoring System (VMS) and our enumerators in Probolinggo 2017 that is $\mathrm{Mr}$. Agga Probo Prayogo, Hariyanto, and Mishariadi Sulasmono. The main contributor to this paper is the first author, while the second and other authors are the team members.

\section{REFERENCES}

Abd-Allah, E., El-Ganainy, A., Osman, A. 2015. Age and Growth of The Areolate Grouper Epinephelus areolatus From Thegulf Of Suez. American Journal of Life Sciences 3(6-1): $7-12$.

Afandy, Z. 2016. Efek Moratorium Izin Kapal Perikanan Terhadap Stok Sumberdaya Ikan di Laut Arafura dengan Permodelan Sistem Dinamik.

Bahtiar, A., Barata, A. Novianto, D. 2013. Sebaran laju pancing rawai tuna di Samudera Hindia. Jurnal Penelitian Perikanan Indonesia 19(4):195 - 202. 
Badrudin, Sumiono, B., Nurhakim, S. 2004. Hook Rates and Compositions of Bottom Longline Catches in the waters of the Arafura Sea. Indonesian Fisheries Research Journal (10)1: 9-14.

Fish Base. 2019. Epinephelus aerolatus Forsskal, 1775.

Gayanilo, F.C. Jr., Sparre, P., Pauly, D. 1996. FAO-ICLARM Stock Assessment Tools (FiSAT) user's Guide (p. 126) FAO Computerised Information Series (Fisheries) No. 8 FAO. Rome.

Gunawan, G., Purbayanto, A., Solihin, I. 2019. Analisa Data VMS untuk Mengidentifikasi Kasus Pelangggaran Kapal Perikanan di Wilayah Kerja Pangkalan Pengawasan Sumberdaya Kelautan dan Perikanan Jakarta. Presentasi pada Seminar Nasional Perikanan Tangkap ke - 8 Institut Pertanian Bogor. 69 - 70.

Hasanudin, M. 1998. Arus Lalu Lintas Indonesia (Arlindo). Oseana 23(2): 1-9.

Ismunarti, D. H. 2014. Analisis Komponen Utama Pada Hubungan Distribusi Spasial Komunitas Fitoplankton Dan Faktor Lingkungan. (Indonesian). Indonesian Journal of Marine Sciences 18(1): 14.

Kadir, N. A., Piah, R. M., Ambak, M. A., Musa, N. 2016. Reproductive Aspects of Aerolate Grouper Epinephelus aerolatus and SixBarred Grouper E. sexfasciatus from Terengganu waters, Malaysia. Bioflux 9(6): 1372-1379.

Mahmoud, H. H. 2009. Gonadal Maturation and Histological Observations of Epinephelus aerolatus and Lethrinus nebulosus in Halaieb / Shalatien Area "Red Sea", Egypt. Global Veterinaria 3(5): 414 - 423.

Mahulette, R. T., Samusamu, A. 2014. Penguatan Kelembagaan Untuk Mendukung Pengelolaan Sumberdaya Perikanan Laut Arafura. Jurnal Kebijakanan Perikanan Indonesia 6 (2): 87 - 96.

Marzuki, S., Djamal, R. 1992. Penelitian Penyebaran Kepadatan Stok dan Beberapa Parameter Biologi Induk Kakap Merah dan Kerapu di Perairan Laut Jawa dan Kepulauan Riau. Jurnal Penelitian Perikanan Laut 68: 49-65.

Mat Piah, R., Kamaruddin, S. A., Abdul Kadir, N. H., Ambak, M. A. 2017. Relationship Between Otolith Measurements with
Aerolate Group, Epinephelus aerolatus in Terengganu, Malaysia. Journal of Fisheries and Aquatic Science: 12: 90-94

Mujianto \& Sugianti, Y. 2014. Bioekologi Ikan Kerapu di Kepulauan Karimunjaya. IImu Kelautan. 19 (2). 88 - 96.

Mulyana, R., Haluan J., Baskoro, S. M., Wisudo, S. H. 2011. Analisis Multidemensional untuk Pengelolaan Perizinan yang Berkelanjutan: Studi Kasus WPP Laut Arafura. Jurnal Teknologi Perikanan dan Kelautan 2(1): 71-79.

Mulyana, R., Haluan, J., Baskoro, M. S., Wisudo, S. H. 2012. Keberlanjutan Perikanan Skala Besar di Laut Arafura. Buletin PSP 20(1): 35-43.

Osman, A. G. M., El-Ganainy, A., Abd-Allah, E. 2018. Some reproductive aspects of the areolate grouper, Epinephelus areolotus from the Gulf of Suez. Egyptian Journal of Aquatic Research 44(1): 51-56

Pranowo, W. S. 2012. Dinamika Uppwelling dan Down welling di Laut Arafura dan Timor. Widyariset 15(2): 415-423.

Pranowo, W. S., Wirasantosa S., Amri, S. N., Dewi, L. C., Ratnawati, H. I., Ati, R. N. A., Prihantono, J., Makarim, S., Hutahean, A. A. 2013. Characteristics of Arafura marine resources and southwest coast of Papua. Research and Development Center for Marine and Coastal Resources, Ministry of Maritime Affairs and Fisheries, Jakarta. (in Indonesian).

Prisantoso, B. I., Badrudin. 2010. Kebijakan Pengelolaan Sumberdaya Ikan Kakap Merah (Lutjanus spp.) di Laut Arafura. Jurnal Kebijakan Perikanan Indonesia 2(1): 71-78.

Purwanto. 2015. Biomasa, Produktivitas Kapal Penangkap dan Potensi Produksi Ikan Demersal di Laut Arafura. Jurnal Penelitian Perikanan Indonesia: 21(3): 187-199.

Ramadyan, F., Radjawane, I. M. 2013. Arus Geostropik Permukaan Musiman di Perairan Arafura-Timor. Jurnal IImu dan Teknologi Kelautan Tropis 5(2): 261-271.

Rochmady \& Susiana. 2014. Pendugaan Stok Ikan Kerapu (Grouper) di Perairan Selat Makassar Sulawesi Selatan Periode Tahun 1999-2007. Jurnal Ilmiah Agribisnis dan Perikanan 7(2): 60-67. 
Sadhotomo, B. \& Suprapto. 2013. Interaksi Antar Trawl dan Rawai Dasar pada Perikanan Kakap Merah (Lutjanus malabaricus) di Laut Timor dan Arafura. Jurnal Penelitian Perikanan Indonesia 19(2): 89-95.

Shakeel, H. \& Ahmed, H in Nickerson, D. J., \& Maniku, M, H (Ed). 1997. Exploitation of Reef Resources: Grouper and Other Food Fishes. Workshop on Integrated Reef Resources Management in the Maldives. Bay of Bengal Program. 119-138.

Sparre, P \& Venema, S. 1999. Introduction Tropical Fish Stock Assessment. (Introduction to Tropical Fish Stock Assessment, language transfer: Fisheries Research and Development Center). Book 1: Manual. Fisheries Research and Development Agency. Jakarta. 438 p.

Suhana. 2015. Kebijakan Kelautan dan Perikanan dan Implikasinya Terhadap Kelestarian Sumberdaya Ikan dan Ekonomi Perikanan Indonesia. Risalah Kebijakan Pertanian dan Lingkungan 2(1): 70-76.

Suman, A. \& Satria, F. 2014. Opsi Pengelolaan Sumberdaya Udang di Laut Arafura (WPP 718). Jurnal Kebijakan Perikanan Indonesia 6(2): 97-104.

Suman, A., Satria, F., Amri, K., Priatna, A., Mahiswara., Suwarso., Zamroni, A., Taufik, M., Panggabean, A, S., Nurdin, E., Ernawati, T., Muklis, N., Tirtadanu., Chodrijah, U., Budiarti, T, W. 2017. Potensi dan Tingkat Pemanfaatan Sumberdaya Ikan di Wilayah Pengelolaan Perikanan Negara Republik Indonesia (WPP NRI) Tahun 2016. 2017. Ref Graphika. 154 p.
Suman, A., Irianto, H, E., Satria, F., \& Amri, K. 2016. Potensi dan Tingkat Pemanfaatan Sumberdaya Ikan di Wilayah Pengelolaan Perikanan Negara Republik Indonesia (WPP NRI) Tahun 2015 serta Opsi Pengelolaannya. Jurnal Kebijakan Perikanan Indonesia 8(2):97-110.

Sumiono, B. \& Hargiyatno, I. T. 2012. Hasil Tangkapan Sampingan pada Pukat Udang dan Alternatif Pemanfaatannya di Laut Arafura. Jurnal Kebijakan Perikanan Indonesia 4(2): 85-91.

Suryanto \& Widodo, A. 2011. The Structure and dynamic of the fishing vessels in Arafura waters in Sumiono,B., Wudianto \& A.Suman (Ed.) : Fish Resources, Fisheries and alternative management in Arafura waters. Pusat Penelitian Pengelolaan Perikanan dan Konservasi Sumberdaya Ikan. Badan Litbang KKP: 79-99

Tadjuddah, M., Wiryawan, B., Purbayanto, A., Wiyono, E. S. 2013. Analisis Parameter Biologi Ikan Kerapu (Epinephelus sp.) di Perairan Taman Nasional Wakatobi, Sulawesi Tenggara Indonesia. Marine Fisheries 4(1): 11-21.

Tambun, R., Simbolon, D., Wahju, R., Supartono. 2018. Zona Potensial Penangkapan Ikan Berdasarkan Musim di WPPNRI 718. Jurnal IImu dan Teknologi Kelautan Tropis 10(3): 757-768.

Wijoprino, Nugroho, D., Sadhotomo, B., Badrudin, M., Suwarso. 2007. Status dan Trend Pemanfaatan Sumberdaya Ikan Laut Arafura. Media Grafika Pratama. Balai Riset Perikanan Laut. 115 p. 